\title{
Iran's Inner Conflict Risk Status ${ }^{1}$ \\ İran'ın İç Kırılganlık Risk Durumu \\ Mehmet Emin SÖNMEZ* \\ Yunus Emre SARAÇ***
}

\begin{abstract}
Throughout history, social events in different parts of the world for different reasons have brought along many changes and transformations. With the emergence of nation states, the internal fragility of the nation states has increased as a result of the drawing of new borders and the coexistence of different social, cultural, religious and economic groups within these borders. One of these countries is Iran. The fact that it has a wide variety of racial, linguistic, sect and economic groups and that it stands out with the Sunni states as the representative of Shiite Theopolitics in the Middle East and its opposition to the USA and Israel increases the risk of internal fragility, both internal and external support of Iran. Today, many different parameters can play a role in the basis of social movements that started largely on an economic basis. In this study, together with Iran's ethnic, linguistic and sectarian diversity, parameters such as the general poverty level of the people and the distribution of oil resources by the provinces were evaluated together with the AHP (Analytical Hierarchy Process) method and a provincialbased possible internal conflict risk map of Iran was created. Considering these maps, some suggestions were made for Iran and Turkey.Because, an Iranian civil war will cause refugees and border security problems for Turkey and the entire Middle East.As a matter of fact, for these reasons, it is extremely important to protect Iran's territorial integrity and internal unity.
\end{abstract}

Keywords: Iran, Civil War, Conflict, AHP, Arc GIS.

$\ddot{O} \mathbf{z}$

Tarih boyunca dünyanın farklı yerlerinde farklı sebeplerden dolayı çıkan toplumsal olaylar birçok değişim ve dönüşümü de beraberinde getirmiştir. Ulus devletlerin ortaya çıkışı ile beraber yeni sınırların çizilmesi ve bu sınırlar dâhilinde farklı sosyal, kültürel, dini ve ekonomik grupların bir arada yaşamaya başlaması neticesinde ulus devletlerin iç kırılganlıkları artmıştır. Bu ülkelerden bir tanesi de İran'dır. Gerek çok çeşitli ırk, dil, mezhep ve ekonomik gruplara sahip olması ve gerek Ortadoğu'da Şii Teopolitiğin temsilcisi olarak hem Sünni devletlerin hem de ABD ve İsrail karşıtlığı ile ön plana çıkması, İran'ın hem iç hem de dış destekli iç kırılganlık riskini arttırmaktadır. Günümüzde büyük ölçüde ekonomik temelli başlayan toplumsal hareketlerin temelinde çok farklı parametreler de rol oynayabilmektedir. Bu çalışmada İran'ın etnik, dil, mezhep çeşitliliği ile beraber halkın genel yoksulluk düzeyi ile petrol kaynaklarının eyaletlere göre dağılışı gibi parametreler AHP yöntemi ile bir arada değerlendirilerek İran'ın eyalet bazlı olası bir iç çatışma risk haritası oluşturulmuştur. Bu haritalar dikkate alınarak hem İran hem Türkiye için bazı önerilerde bulunulmuştur. Çünkü olası bir İran iç savaşı başta Türkiye olmak üzere tüm Ortadoğu için mülteci ve sınır güvenliği başta olmak üzere büyük problemlere neden olacaktır. Nitekim bu nedenlerden dolayı İran'ın toprak bütünlüğü ve iç birliğinin korunması son derece önemlidir.

Anahtar Kelimler: İran, İç Çatışma, Kırılganlık, AHP, Arc GIS.

\section{Introduction}

In many studies, it has been determined that the basic parameters determining the risk of internal conflict are related to the political and social situation as well as racial, religious, cultural, ideological and economic factors (Kim, 2006, s. 91; Jackson, 2001, s. 65-66). The most important of these is the economic one. As a matter of fact, referring to Kuznets (1955) and Kuznets (1966), Kim (1998) is of the opinion that income inequality between traditional rural and advanced industrialized areas in an area is the main cause of internal conflicts. In the postrevolutionary period in Iran, a rapid urbanization adventure has started and this situation has increased gradually in the social and cultural areas between rural and urban, existing cities and

\footnotetext{
${ }^{1}$ This work was produced from the Master's Thesis titled "The Effects of a Possible Iranian Civil War on Turkey" which had been prepared in the Department of Security Strategies and Management, Gaziantep University, Social Sciences Institute, within the scope of the BAP project no. FEF. YLT.19.01.

* Prof. Dr., Gaziantep Üniversitesi, Fen Edebiyat Fakültesi, Coğrafya Bölümü, eminsonmez@gantep.edu.tr

** Güvenlik startejileri ve yönetimi uzmanı, emresaracy@gmail.com
} 
existing neighborhoods of the cities, especially in the economy (Fanni, 2006, s. 410). Therefore, urban, rural and general poverty have been evaluated as important parameters in the risk of internal conflict in Iran.

Civil conflicts and civil wars, as in many cases from past to present, start with social movements that emerge largely due to many economic, political, racial and cultural reasons. As a result of these social movements that emerged on different foundations, generally ignored by the state or tried to be suppressed with violence, popular movements grow and turn into violent acts (Deniz, 2015, s. 75-77). Internal conflicts are not limited to the region or countries where they arise, but also expose the regions and countries in their immediate vicinity or the regions and countries they interact with, to serious adversities and destructive problems (Canyurt, 2018, s. 1104). For example, primarily Syria civil war which began in 2011, Turkey, Lebanon and Jordan to Europe, including an expanding field has led to the emergence of many problems. Similarly, the civil war that emerged in the Central African Republic reflected on the neighboring countries, and the region, which was already in a state of economic weakness, became worse and financial resources were invested in the arms sector, not humanitarian investments. As a matter of fact, Cameroon, Chad and Congo Republics were also affected by this instability and thus caused the region to drift into a more unstable and chaotic environment (Tüysüzoğlu, 2013, s.114-120). Therefore, instability and chaos occurring in only one country can cause negativity in all surrounding regions in a short time. Therefore, Syria, Iraq, Egypt, as in the example of a possible internal conflicts that can occur in Iran will not be limited to Iran and especially Turkey and surrounding countries all over the world can say that adversely affect.

Although the development of social movements and their transformation into conflict is largely dependent on their own internal dynamics and cannot be subjected to a certain generalization (Gersovitz \& Kriger, 2013, p.160), four basic factors are generally accepted for internal conflicts and economic conditions are deterioration is accepted as the most important factor among them. Indeed, there are many data showing that economic reasons play a dominant role, especially in the emergence of social movements emerging today. For example, those who participate in economic protests are at a higher level in Tunisia, nearly three times the political demonstrators (Gelvin, 2014, p. 67). As a matter of fact, it has been stated in other studies that the economy is one of the most important factors on internal conflict (Collier \& Hoeffle, 2004, p. 587-589; Collier, 2000, p. 24; Egnal, 2011, p. 29). Especially oppressive political regimes that determine the breaking points of changes and transformations follow economic conditions. Although it is less important than the first two reasons, the problems experienced in renewable resources take the third place. Ethnic differences emerge as another important reason and may be a sufficient reason alone in some countries. This risk increases even more, especially if large groups that may conflict with one another are present in the same country (Parsons \& Merton, 2011, p. 235). Apart from these four factors, another factor that can form the basis of social conflicts in different parts of the world as in Iran is religious and sectarian differences (Şen and Şen, 2015, s. 124-125). In addition to these, it is possible to say that there are many different parameters such as the inability to make reforms especially related to the expansion of rights and freedoms, the imposition of unjust punishments and unjust detentions due to political accusations, and the inadequacy of the steps taken towards freedom of belief and expression (Altundeğer and Y1lmaz, 2016: 290). In countries where ethnic and religious or sectarian diversity is high but monocultural policies that control them are implemented, the risk of internal conflict increases even more (Fearon \& Laitin, 2003, p. 75). Therefore, in a country such as Iran, where minority groups live intensely, discrimination against the religions and languages of minority groups appear as important parameters that can trigger a civil war. 
In addition to all these, the division of ethnic, cultural and religious groups may pose another risk in terms of internal conflicts, especially while drawing state borders (DIAS, 2013). It is possible to see this situation on a larger scale in cities such as Belfast, Jerusalem, and Nicosia. For example, while sect and religion are prominent in Belfast and Jerusalem, there is a racial discrimination in Nicosia (Pullan, 2011). Therefore, in this study, these parameters have been used as determining factors of a possible internal conflict risk in Iran. Indeed, internal conflicts are also classified as racial, religious, ideological and economic.

Since each region has its own geographical and cultural codes, while determining the parameters that can play a role in a possible Iranian civil war, Iran's own internal dynamism was taken into consideration in this study. We can say that ethnic and linguistic structure, sectarian features, income situation and economic resources are important internal dynamics for Iran. Therefore, in this study, these dynamics are evaluated as the dynamics of a possible Iranian civil war.

\section{Study Area}

In this study, Iran, one of the most important geopolitical states of the Middle East, is the subject of the study. As Iran is located at the center of the Asian Continent and Middle East geography, its geopolitical importance increases more. Iran is very difficult to occupy because it is surrounded by high mountains on three sides and the ocean and sea on the other. In addition, it has a great advantage with its 1.684 million $\mathrm{km} 2$ area and a population of nearly 85 million, both with its territorial dominance and population potential (Stratfor, 2011). In addition to being in a position that connects the Eastern Mediterranean, Asia, Africa and Europe to each other, being in the center of Shia Islam increases the geopolitical importance of Iran. Being the largest Shia state at the center of Muslims and its proximity to Israel enabled Iran to play a key role in destabilizing its region (Ehteshami \& Mohammadi, 2017, s. 6). It has also hosted important civilizations between Anatolia and India and the Caspian Sea and the Persian Gulf. Thus, it has a very important geopolitical position as it acts as a gateway between East and West and North and South, and commercial roads pass through here (Karadeniz, 2012, s. 17). In addition, Iran's proximity to the Caucasus and Central Asian Turkish States, which is a part of the historical trade route connecting China and Europe, makes Iran more important in many ways (Chitadze, 2012, s. 5). For these reasons, Dilip Hiro emphasized the importance of its geopolitical position by saying "Iran is probably the most strategic country of this planet" (Sarıkaya, 2008, s. 15). As a matter of fact, Brzezinski calls Iran "Geopolitical Axis" (Adıbelli, 2017, s. 127). This geopolitical position gives Iran the advantage of having a say in regional affairs. In addition, due to its geopolitical advantages, it does not suffer much in the supply of raw materials and general needs and ensures that embargoes do not create the desired negative effect (Birsel, 2013, s. 22).

The surrounding geographies are also important for Iran. In this respect, one of the basins that Iran attaches importance to geopolitically is the Caspian Sea. The main reasons why the Caspian Sea is geopolitically important for Iran is that the Caspian Sea is rich in natural gas and oil, and access to the Persian Gulf can be made through Iran for its shipment (Davutoğlu, 2011, s. 27; Davutoğlu, 2012, s. 427). In addition, the Caspian Sea is an important geopolitical area with the transportation of goods between the countries of the region and between Europe and Southwest Asia and rich caviar production. Iranians constitute $50 \%$ of the 12 million population living around the Caspian Lake (Zeinolabedin, Yahyapour, \& Shirzad, 2009, p. 116117). Bu nedenle Hazar denizinin kontrolünde de İran önemli bir yere sahiptir. The Persian Gulf constitutes another of the most geopolitically important areas for Iran. The Persian Gulf is almost the only route in terms of the supply of oil and natural gas in the region to the world (Elçi, 2019: 154). This situation caused Asian states such as China, which are dependent on the energy of the Persian Gulf, to become involved in the events in the region. Therefore, control 
of the Persian Gulf is of greater importance for Iran (Barnes \& Jaffe, 2006, p. 157). In addition, the Persian Gulf stands out as the most important competition area among the countries riparian with the Gulf (Konukçu, 2018a, s. 24). The Strait of Hormuz is the most strategic point of the Persian Gulf (Davutoğlu, 2012, s. 162), and the Çabahar Port and Iran are trying to keep the Strait of Hormuz under control in general terms (Tüysüzoğlu, 2011, s. 46). The fact that the Persian Gulf is an important energy, production and transportation area has also increased the chemical, biological and nuclear armament in the region, thus increasing the geopolitical importance of Iran, which is an important power controlling the region (Barnes \& Jaffe , 2006, p. 143).

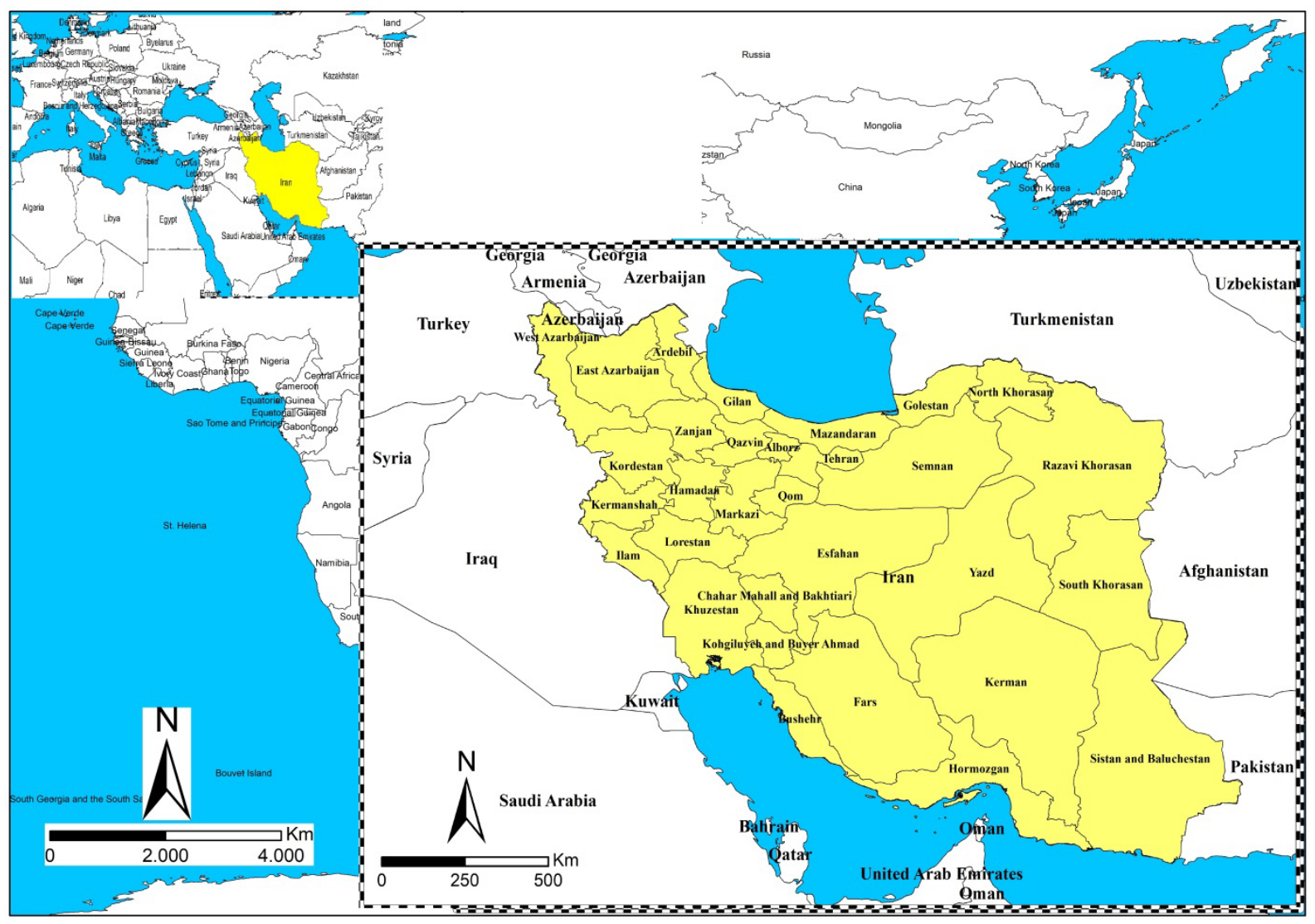

Figure 1. Location Map of Iran.

The strategy that Iran has invested the most in geopolitical terms is the Shia Crescent policy (Salihi, 2019, s. 183). Iran wants to ensure the Thpolitical dominance of Shiism in the Middle East geography starting from its own geography up to Egypt with the Shia Crescent policy (Ekşi, 2017, s. 47; Konukçu, 2018b, s. 82). Especially due to the Shia Crescent policy, it attempts costly operations in Iran, Syria, Yemen, Iraq and Lebanon with both hard power and soft power (Bilgetürk, 2018, s. 400; Sanyürek, 2018, s. 1140). The most serious argument used by Iran in this policy is the belief in Mahdi and the inclusiveness of this belief (Erol and Bilgetürk, 2020, s. 272-273).

In addition, Russia's convergence with Iran against American expansionism and its cooperation with Iran in order to dominate the Middle East, Caucasus and Central Asia has increased the importance of Iran today (Omelicheva, 2012, p. 333). The political mission that Iran has assumed is based on the sense of self that implies power and control in the country and opposition outside (Ehteshami \& Mohammadi, 2017, p. 6), which is mostly applied through sect and nationalism. As a matter of fact, the attempt to lead in Palestine, Saudi Arabia and Gulf 
countries, including Iraq, Syria, Lebanon, puts Iran against other countries in the region (Macdonald, 2002, p. 26).

Iran north of Armenia, Azerbaijan, while adjacent to the Caspian Sea and Turkmenistan, Afghanistan and Pakistan, east, south and west by the Indian Ocean, the Persian Gulf is bordered by Iraq and Turkey. This position, on the one hand, puts Iran at the center of the Middle East Geography, on the other hand, has made it an important transition point between North and South and East and West. It is also the only country that can provide a direct link between the Caspian Sea and the Persian Gulf and the Indian Ocean (Figure 1).

Another important element that makes Iran different in the region is the Pro-resistance Islamic Revolution that took place in Iran in 1979. Indeed, after the 1979 Islamic Revolution, Iran's foreign policy developed as Pan- Islamist, Pan-Shiite, anti-Western, Anti-Zionist, AntiImperialist and pro- resistance (Golmohammadi, 2019, p.93). In the time of Khomeini, this Islamic revolution was used as a unifying element and brought the ruling elites together and channeled them into a particular political space. However, after the death of Khomeini, serious differences and conflicts emerged among the ruling elites over economic, socio-cultural and foreign policy issues (Rakel, 2008, p. 24). While this ideological approach, which is based on Shia Islam and built on insurgent assumptions, caused Iran to be isolated from the international arena (Amiri, 2010, p.205), it has become the driving force for the continuation of the Iranian ruling elite in domestic policy (Golmohammadi, 2019, p. 94). As Persian nationalism was added to the revolutionary Islamic tradition in Iran and used in domestic politics, it caused the deterioration of Iran's relations with its neighbors, Muslim states and even the USA. When the attitudes of adventurous and pragmatic figures are added to this, the foundations of today's Iranian domestic and foreign politics have emerged. Thus, the foreign policy of the Islamic Republic in Iran has been shaped by the historical experiences of Iran, Iranian nationalism, revolutionary Islam, economic weakness and opportunity and personalities (Jones, 2009, p. 84). But the most important of these is the Islamic Revolution's capacity to keep Iran's domestic and foreign policy under control implicitly. That is, the Islamic revolution is not to perfect the state; The Islamic Republic of Iran has been turned into a tool to support and perfect the revolution (Ansari \& Aarabi, 2019, p.13). This is why the Iranian Islamic Revolution has become an important geopolitical argument that determines the structure, ideology, economy, domestic and foreign policies of the state.

\section{Material and Method}

In the study, it has been revealed in which provinces that social movements or fragility in Iran carry more risks. In order to reveal the social, cultural and economic fragility of Iran, the ethnic structure, religion, language and economic status of the Iranian people were used. In order to reach these parameters, a wide literature review was made and the obtained data were compared by many sources. A possible internal conflict risk map of Iran was created by evaluating a total of 15 parameters under the titles such as ethnic structure, language, sect and poverty situation. These data on Iran (World Bank, 2020; DEIK, TIM, \& KPMG, 2020; mfa.gov.tr, 2019; Barrett, 2014; Ranjipour, 2020; Einian \& Souri, 2020) were obtained from various institutions and studies. The obtained data were subjected to the AHP method and evaluated in the Arc GIS program, and a possible Iran civil war risk map was created. 


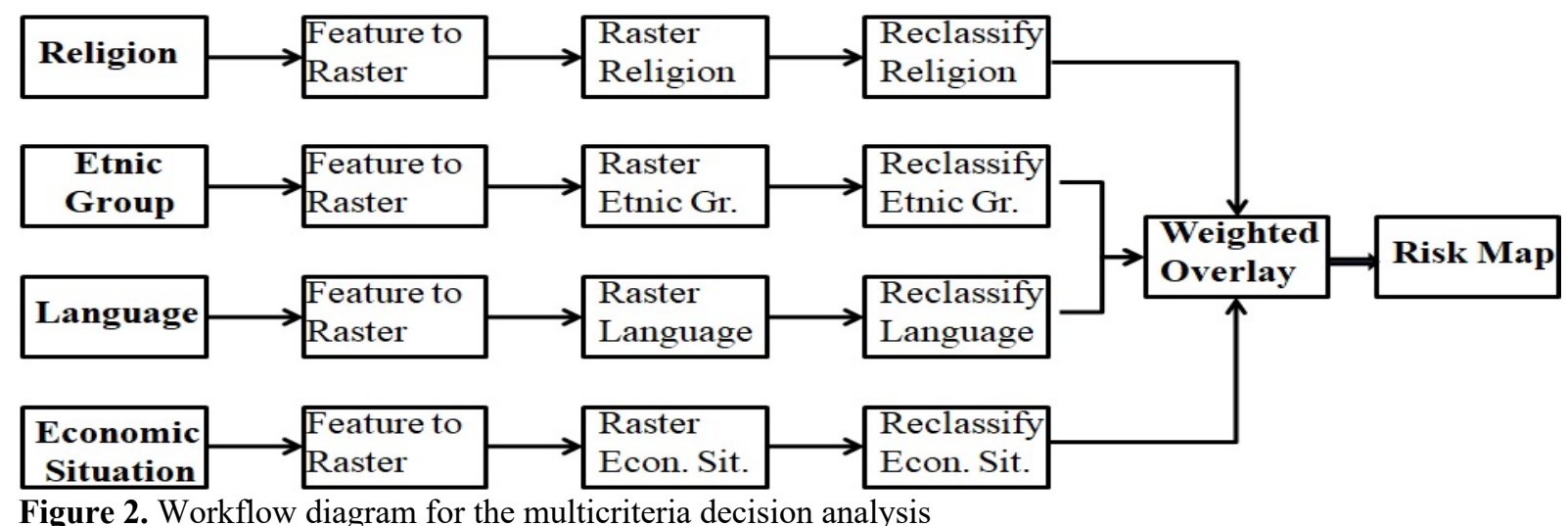

Figure 2. Workflow diagram for the multicriteria decision analysis

Analytical Hierarchy Model (AHP) has been used to determine the fragility of Iran according to the above mentioned parameters. This model is based on many physical issues such as landslide and earthquake risk analysis (Boroumandi, Khamehchiyan, \& Nikoudel, 2014; Sönmez, 2011), determination of solar energy potential (Kum, Sönmez, \& Karabaş, 2019) as well as the selection of the best livable city from boiler management. (Bahurmoz, 2006) and selection of suitable species for industrial afforestation (Şen \& Güngör, 2018), it is used in the analysis of many problems of human origin. Indeed, AHP method, which is used in many different fields, is one of the GIS-supported Multi-Criteria Decision Making (MCDM) methods and analyzes qualitative and quantitative criteria with a binary comparison and scoring scale (Wind \& Saaty, 1980; Ünal, 2012; Saaty, 1990). Matrix is obtained based on paired comparisons and the weights of these criteria in the general are determined. The AHP method models the relationship of not only basic parameters but also sub-parameters in a certain hierarchical structure in the binary comparison method. Thus, it enables the interpretation of the experience, knowledge, understanding and intuition of the conductor in the computer environment (Özdemir \& Saaty, 2006; Ünal, 2012). Due to these flexible features, the AHP method becomes more flexible and thus it seems that it can give much healthier results in planning studies where environmental problems are constantly increasing and environmental sensitivity must be taken into consideration (Kum, Sönmez, \& Karabaş, 2019). With the thought that better results can be obtained, AHP method, one of the Multi-Criteria Decision Making methods, was used in this study. 
Table 1. Pairwise comparison matrix for parameters.

\begin{tabular}{|l|c|c|c|c|c|c|c|c|c|c|c|c|c|c|c|}
\hline & $\begin{array}{c}\text { Energy } \\
\text { Sources }\end{array}$ & $\begin{array}{c}\text { Urban } \\
\text { Poverty }\end{array}$ & $\begin{array}{c}\text { Rural } \\
\text { Poverty }\end{array}$ & $\begin{array}{c}\text { General } \\
\text { Poverty }\end{array}$ & $\begin{array}{c}\text { Religion } \\
\text { (Sect) }\end{array}$ & Kurdish & Turkish & Arabic & $\begin{array}{c}\text { Beluc } \\
\text { L. }\end{array}$ & $\begin{array}{c}\text { Persian } \\
\text { L. }\end{array}$ & Kurd & Turk & Arab & Beluc & Persian \\
\hline $\begin{array}{l}\text { Energy } \\
\text { Sources }\end{array}$ & 1 & 0.20 & 2.00 & 0.33 & 0.12 & 3.00 & 0.33 & 3.00 & 3.00 & 9.00 & 0.14 & 5.00 & 0.33 & 0.20 & 7.00 \\
\hline $\begin{array}{l}\text { Urban } \\
\text { Poverty }\end{array}$ & 5.00 & 1 & 7.00 & 3.00 & 0.33 & 8.00 & 3.00 & 8.00 & 8.00 & 9.00 & 3.00 & 7.00 & 3.00 & 3.00 & 9.00 \\
\hline $\begin{array}{l}\text { Rural } \\
\text { Poverty }\end{array}$ & 0.50 & 0.14 & 1 & 0.20 & 0.11 & 2.00 & 0.33 & 2.00 & 2.00 & 5.00 & 0.20 & 2.00 & 0.33 & 0.33 & 5.00 \\
\hline $\begin{array}{l}\text { General } \\
\text { Poverty }\end{array}$ & 3.00 & 0.33 & 5.00 & 1 & 0.14 & 7.00 & 3.00 & 7.00 & 7.00 & 9.00 & 3.00 & 7.00 & 3.00 & 3.00 & 9.00 \\
\hline $\begin{array}{l}\text { Religion } \\
\text { (Sect) }\end{array}$ & 8.00 & 3.00 & 9.00 & 7.00 & 1 & 9.00 & 5.00 & 9.00 & 9.00 & 9.00 & 5.00 & 9.00 & 5.00 & 7.00 & 9.00 \\
\hline Kurdish & 0.33 & 0.12 & 0.50 & 0.14 & 0.11 & 1 & 0.20 & 1.00 & 1.00 & 2.00 & 0.14 & 2.00 & 0.50 & 0.33 & 5.00 \\
\hline Turkish & 3.00 & 0.33 & 3.00 & 0.33 & 0.20 & 5.00 & 1 & 7.00 & 5.00 & 9.00 & 0.33 & 5.00 & 3.00 & 2.00 & 9.00 \\
\hline Arabic & 0.33 & 0.12 & 0.50 & 0.14 & 0.11 & 1.00 & 0.14 & 1 & 1.00 & 5.00 & 0.14 & 5.00 & 1.00 & 1.00 & 5.00 \\
\hline Beluc L. & 0.33 & 0.12 & 0.50 & 0.14 & 0.11 & 1.00 & 0.20 & 1.00 & 1 & 5.00 & 0.14 & 3.00 & 0.33 & 0.20 & 5.00 \\
\hline Persian L. & 0.11 & 0.11 & 0.20 & 0.11 & 0.11 & 0.50 & 0.11 & 0.20 & 0.20 & 1 & 0.11 & 0.20 & 0.20 & 0.11 & 1.00 \\
\hline Kurd & 7.00 & 0.33 & 5.00 & 0.33 & 0.20 & 7.00 & 3.00 & 7.00 & 7.00 & 9.00 & 1 & 7.00 & 3.00 & 2.00 & 9.00 \\
\hline Turk & 0.20 & 0.14 & 0.50 & 0.14 & 0.11 & 0.50 & 0.20 & 0.20 & 0.33 & 5.00 & 0.14 & 1 & 0.20 & 0.14 & 3.00 \\
\hline Arab & 3.00 & 0.33 & 3.00 & 0.33 & 0.20 & 2.00 & 0.33 & 1.00 & 3.00 & 5.00 & 0.33 & 5.00 & 1 & 0.50 & 5.00 \\
\hline Beluc & 5.00 & 0.33 & 3.00 & 0.33 & 0.14 & 3.00 & 0.50 & 1.00 & 5.00 & 9.00 & 0.50 & 7.00 & 2.00 & 1 & 7.00 \\
\hline Persian & 0.14 & 0.11 & 0.20 & 0.11 & 0.11 & 0.20 & 0.11 & 0.20 & 0.20 & 1.00 & 0.11 & 0.33 & 0.20 & 0.14 & 1 \\
\hline
\end{tabular}

A total of 15 parameters of economic and demographic origin were used in the study. The racial distribution of the people living in Iran, the languages they speak, the rural, urban and general poverty situations and the distribution of economic resources are considered as different parameters. In the AHP method, the average values in the international literature were used to determine the weight values of these parameters. Especially in areas where the general population density is between $0-30 \%$, which determines the spatial segregation in a place, the view that there is a low level of segregation, a moderate level of segregation at $30-60 \%$ and a high level of segregation in areas higher than 61\% (Massey and Denton, 1993: 20), the same rates were used in this study. For example, depending on the distribution of Kurdish in Iranian provinces, the density of the population, which is the subparameters of Kurdish, according to the provinces is taken as a basis. In this case, states such as Yazd or Fars, which are lower than $10 \%$, are scored with 1, Kermanshah between 50-60\%, which is between 10-30\%, and the state of Kurdistan, where Kurdish is spoken more than $61 \%$, is scored with 9, which is the highest.

Table 2. Weighted classification of parameters and sub-parameters.

\begin{tabular}{|c|c|c|c|c|c|c|c|}
\hline Effective Factors & $\begin{array}{l}\text { Factor } \\
\text { Classes }\end{array}$ & $\begin{array}{c}\text { GIS } \\
\text { Class } \\
\text { Value } \\
\end{array}$ & $\begin{array}{l}\text { GIS } \\
\text { Weight } \\
\text { Value } \\
\end{array}$ & $\begin{array}{c}\text { Effective } \\
\text { Factors }\end{array}$ & $\begin{array}{l}\text { Factor } \\
\text { Classes }\end{array}$ & $\begin{array}{c}\text { GIS } \\
\text { Class } \\
\text { Value } \\
\end{array}$ & $\begin{array}{l}\text { GIS } \\
\text { Weight } \\
\text { Value }\end{array}$ \\
\hline \multirow{7}{*}{ Kurd } & $0-10$ & 1 & \multirow{7}{*}{0,109} & \multirow{7}{*}{ Kurdish } & $0-10$ & 1 & \multirow{7}{*}{$\mathbf{0 , 0 1 9}$} \\
\hline & $10,1-20$ & \multirow{2}{*}{3} & & & $10,1-20$ & 3 & \\
\hline & $20,1-30$ & & & & $20,1-30$ & 3 & \\
\hline & $30,1-40$ & 5 & & & $30,1-40$ & 5 & \\
\hline & $40,1-50$ & \multirow{2}{*}{7} & & & $40,1-50$ & \multirow{2}{*}{7} & \\
\hline & $50,1-60$ & & & & $50,1-60$ & & \\
\hline & $60+$ & 9 & & & $60+$ & 9 & \\
\hline \multirow{7}{*}{ Turk } & $0-10$ & 1 & \multirow{7}{*}{0,014} & \multirow{7}{*}{ Turkish } & $0-10$ & 1 & \multirow{7}{*}{$\mathbf{0 , 0 7 7}$} \\
\hline & $10,1-20$ & \multirow{2}{*}{3} & & & $10,1-20$ & 3 & \\
\hline & $20,1-30$ & & & & $20,1-30$ & 3 & \\
\hline & $30,1-40$ & 5 & & & $30,1-40$ & 5 & \\
\hline & $40,1-50$ & \multirow{2}{*}{7} & & & $40,1-50$ & \multirow{2}{*}{7} & \\
\hline & $50,1-60$ & & & & $50,1-60$ & & \\
\hline & $60+$ & 9 & & & $60+$ & 9 & \\
\hline Arab & $0-10$ & 1 & 0,045 & Arabic & $0-10$ & 1 & 0,026 \\
\hline
\end{tabular}




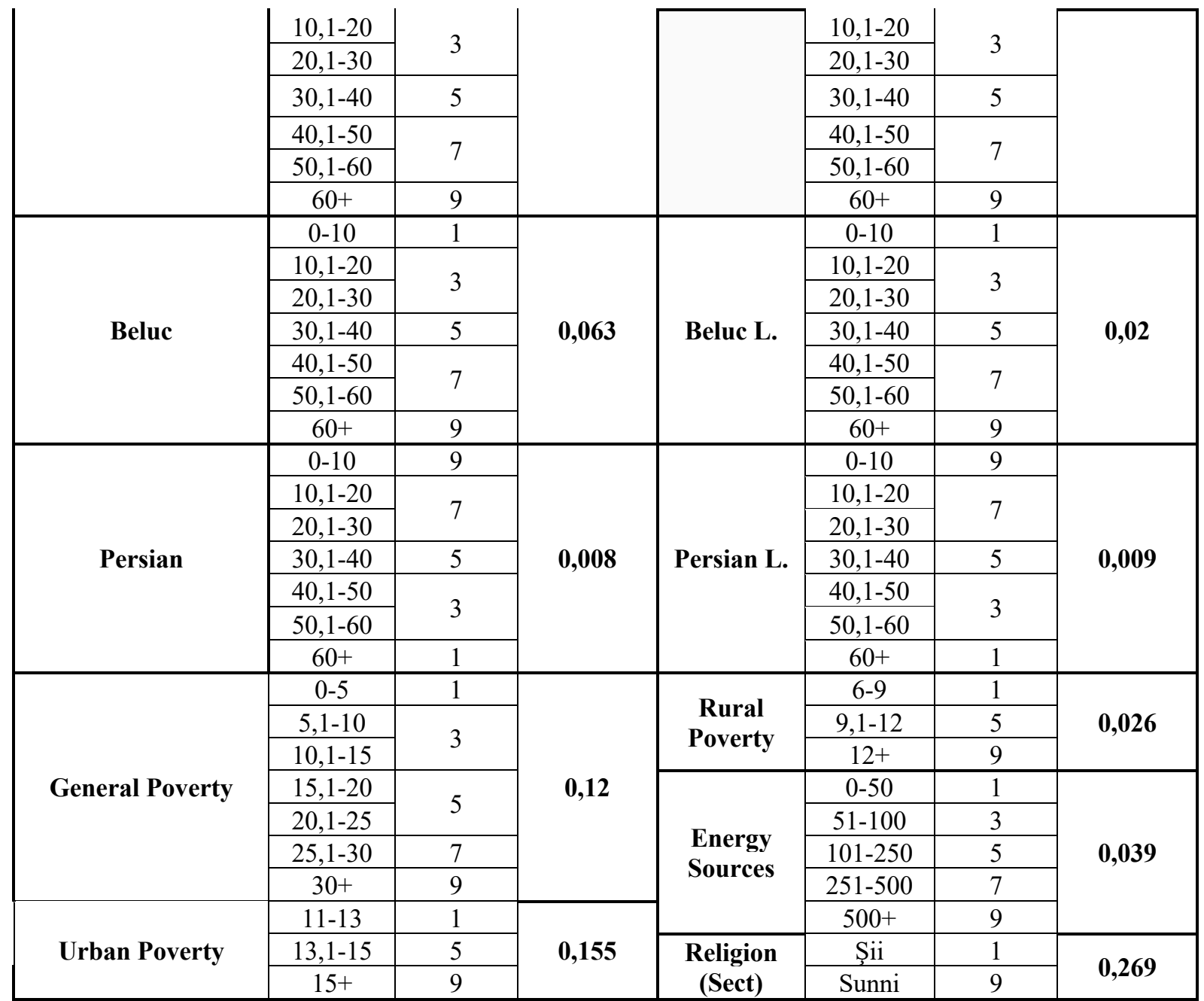

In the study, literature review and sociological and political characteristics of Iran were taken into consideration to determine the weight value of the parameters. For example, in a study conducted in the USA, it was determined that the most important parameter that plays a role in the spatial separation of individuals is the state of wealth with 0.456 , followed by the poverty level with 0.323 , and education and other cultural elements come after them (Florida and Mellander, 2017, p. 9). Although these values were taken into consideration in this study, it was also taken into consideration that especially Iranian geopolitics are sectarian-based and that different dynamics come to the fore in Iran and the weight values of the parameters were assigned accordingly.

\section{Sectarian Features}

According to statistical data, although $99 \%$ of Iranian people are Muslims, $90 \%$ of Muslims are Shiites and 9\% are Sunnis, and other religions have only $1 \%$ of the population (https: //www.aa. com.tr, 2019). The fact that the religious structure in Iran can be considered as homogeneous has been the most important factor in prioritizing the religious identity rather than ethnic origin in identifying the identity of individuals (Gürkaş, 2007, s. 71). This situation is of great importance for the unity and integrity of Iran.

With the 1979 Revolution, although the idea of being an Iranian and an ummah that melted Islam in a pot was adopted, in time the ummah discourses were replaced by approaches based on Persian national identity and being Iranian. Shiism, on the other hand, has been reflected in the society as a supreme identity and ideology, and a Shia-based political model 
has been implemented in Iran (Yavuz, 2014, s. 92-93). Therefore, while Iran constructs a policy on nationalist-national identity within itself, it defines itself with the emphasis on Shiism in foreign policy. In fact, Iran's clear attitude towards Israel transcended the Shiite identity and assumed the upper identity of Islam supported by all Muslim peoples and found support.

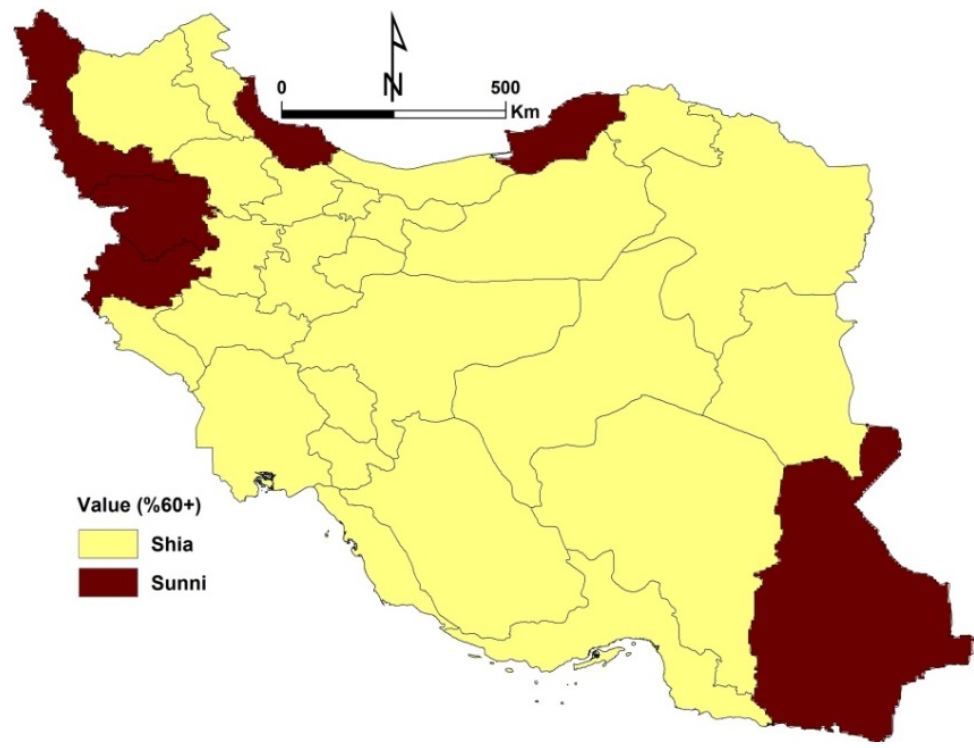

Figure 3. The density of sects of the provinces in Iran $(60 \%+)$.

Although there is a serious Shiite mobilization, Sunni groups also continue to exist within Iran, and Kurds, Balochis and Turkmens stand out as Sunni groups. Due to these religious structures, Kurds and Balochi have been subjected to various systematic and severe violations of rights such as the regime's Persianization and Shiaization policies (Saraçl1, 2008, s. 169). The Sunni community, which corresponds to approximately $10 \%$ in terms of demographics, mostly live in Sistan-Baluchistan, Kurdistan and Gulistan (Figure 9). The fact that the provinces of Sistan-Baluchistan and Kurdistan are the poorest and backward provinces of Iran shows that sectarianism is very effective in Iran.

As with the religions accepted by millions, Islam tends to take the social, cultural, political and economic colors of its immediate environment (Barrett, 2014, p. 9). Even though religion itself may appear to be the same, its practice and manifestation largely depends on the local setting. Iran, which has made the unique dynamics of Shiism with its mission in the historical process, a life vision, is one of the countries where religious dynamics mostly interfere with social, cultural, political and economic life in the world. Therefore, the parameter that will be the most influential in Iran's social, cultural and economic fragility emerges as religion.

\section{Ethnicity and Language}

According to the statistical data, it is possible to classify Iran in 5 ethnic elements as Persians 50\%, Turks 26\%, Kurds $11 \%$, Arabs 5\% and Baloch $3 \%$ at the basic level (Beşiriye, 2009, s. 13). Persian is located in the Indo-Aryan wing of the Indo-European language family, it is the official language in Iran and is used as a mother tongue by $60 \%$ of the Iranian population and a second language by $15 \%$. Since it is the official language of the country, there are no restrictions or political problems regarding this language. For this reason, Persian and Persian languages appear as the least dangerous parameters in terms of internal conflict risk. 


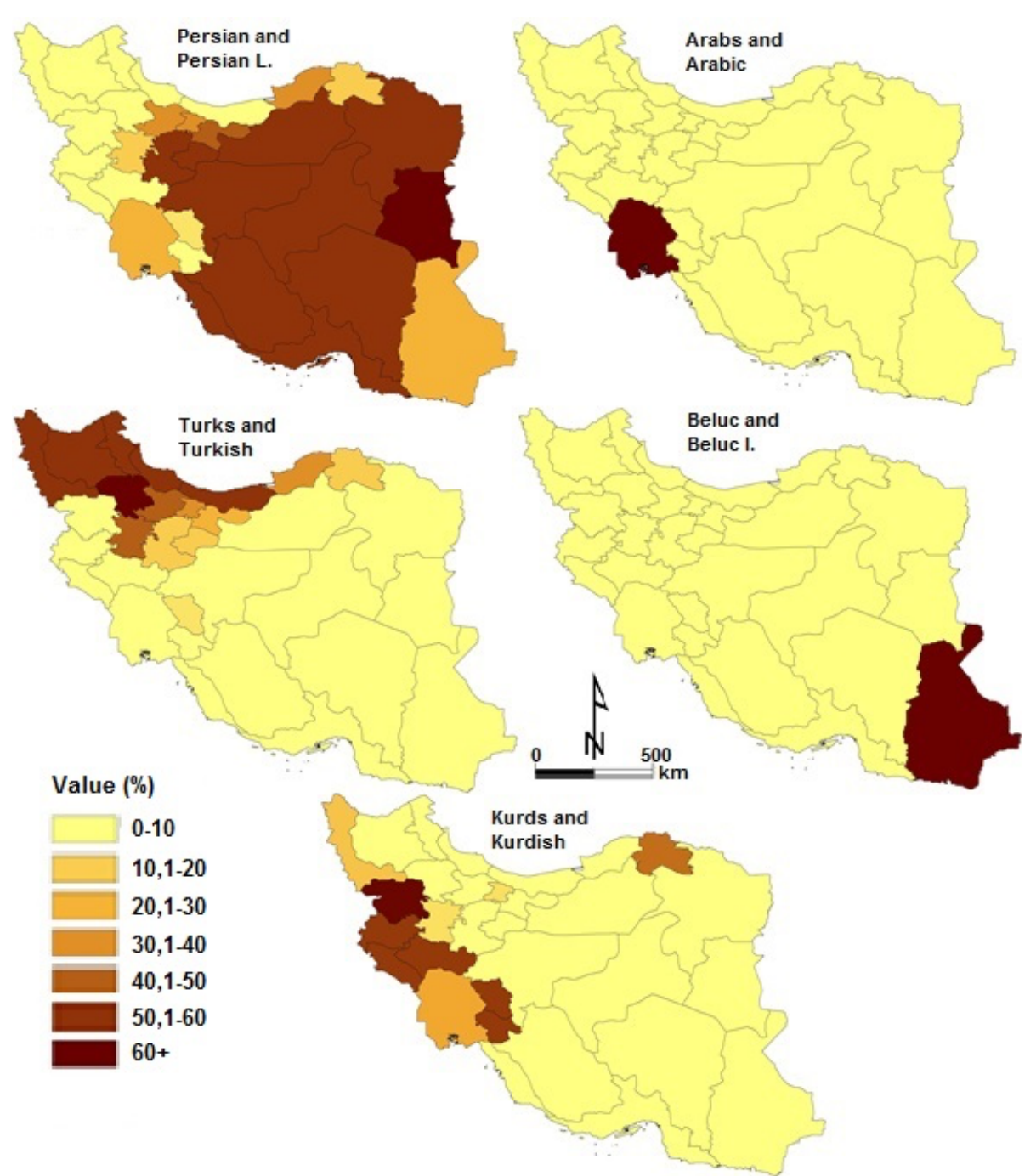

Figure 4. Iran's ethnic structure and most spoken languages.

Although Azerbaijani Turks are concentrated in Tabriz, East Azerbaijan, West Azerbaijan and Ardabil regions, they also constitute the majority of the population in Zanjan, Qazvin, Tehran, Hamadan, Kum, Mashhad and Kerec regions (Erendor, 2018, s. 209). In Iran, the Azerbaijani population estimated to be around 25 million in 2008 (Saraçli, 2008, s. 173), according to a study conducted in 2018, is more than 30 million and corresponds to approximately $33 \%$ of the total population (Erendor, 2018, s. 307). ). According to the Azerbaijani Turks, who have removed Iran's most important religious authorities from their honor, the Islamic Revolution is considered as the revolution of the Azeri religious leaders. Azerbaijani Turks are the building blocks of Iran in the religious sense, as well as they are very effective and influential in Iran's political, cultural and economic areas (Saraçli, 2008, s. 174).

The Sunni Turkmens are predominantly located in Northern Horosan and Gulistan, in the border regions of Iran with Turkmenistan. Located in the southeast of the Caspian Sea, this region is also called the Turkmen Sahara. Therefore, Khorasan Turks are accepted as Turkmen because they live in the same region (Atmaca, 2012, s. 84). Turkmens, who are not very influential in Iranian internal dynamism, experience problems due to certain cultural assimilations.

Turkish, which is the most spoken language in Iran along with Persian, has not been subjected to any pressure for a long time, but starting from the Riza Shah period, oppression and assimilation policies towards Turkish have been implemented. Turks, on the other hand, 
tried to preserve their language by carrying out broadcasting activities (Boylu and Temizyürek, 2015, s. 95). It is accepted that especially Azerbaijani Turks have the character to act for their own future if they gain full awareness of language, and some rights such as education in Turkish mother tongue are sometimes restricted by the regime (Erendor, 2018, s. 310). In particular, the pressures during the reign of Reza Shah and the national awakening that emerged as a result, the Babek Castle marches in 1999, the Iranian state's support of the Armenians in the NagornoKarabakh conflict, the humiliation of the Turks in various media outlets, and the prevention of the Traktör team's championships established in Tabriz in 1970 (Çetin, 2017, s. 325) are some of the problems that Azerbaijani Turks face in Iran.

Kurds in Turkey, Iraq, as well as to live in a geographic region which borders Azerbaijan and the West in general are known to be as Sunni (Eroglu, 2016, s. 28). Iran, which does not face a problem for the Shia Kurds who keep up with the regime policies, has a problematic relationship with Sunni Kurds through constant separatism. Although almost all of the city of Kurdistan is Kurdish in Iran, there is a significant amount of Kurdish population in the provinces of Kurdistan, Northern Horosan, West Azerbaijan and Kermanshah (Bahtaran). In addition, Kirmanşah, Urmiye, Bijar, Piranşehr, Hoy, Serdeşt, Sunkur, Maku, Salmas, Miyandub, Nakade, Bane, Bijar, Chios, Senendaj, Kurve, Merivan, Pave, Mahabat, Kasr-1 Şirin are other areas where Kurds live intensely (Figure 4). The ethnic, sectarian and economic heterogeneity of these regions where Kurds live is also effective in the emergence of intense conflicts (Atmaca, 2012, s. 47-48). They were subjected to severe pressure during the period of Muhammed Riza Pehvlevi and thus they turned to armed actions (Yenisey, 2008, s. 200-202). These movements, which lacked a certain organization, turned into an organization called the Kurdistan Free Life Party (PJAK) in 2003, as an organization affiliated to the PKK, in order to carry out armed action in Iranian territory. During the Arab Spring, the demands of the Kurds in Iran also differed, although not as much as the Kurds in other countries, the ideas of independence in Iran have become more discussed (Karadağ, 2019, s. 2). There is no major restriction on Kurdish in Iran. As a matter of fact, Kurds in Iran have rights such as media activity in their own language, the right to education in the mother tongue in their universities, and they are the most privileged language among minority groups (Okyar, 2014, s. 239).

Another minority in Iran is Balochis and they live in the southeast of Iran, in the southwest of Afghanistan and in the east of Pakistan geography. Baluchistan, which is far from the central regions of Iran, has geographical, cultural and racial ties with Balochistan province in Pakistan and Balochi region in Afghanistan (Hafeziniya, 2017, s. 129). Balochi have a strong feudal cultural and social structure with strong tribal and tribal ties (Tüysüzoglu, 2013, s. 423).

In Iran, it is possible to broadcast many works in Balochi language, which is not subject to any significant restrictions, and radio broadcasting is also allowed. In any case, Balochis do not make any demands regarding their language, because of the lack of education of the Baloch people and their language being underdeveloped (Tüysüzoglu, 2013, s. 428). Despite the economic inadequacy, the opening of Baluchistan to the Arabian Sea and the fact that it has the Çabahar Port, which enables to control the Strait of Hormuz, increases its strategic importance. In addition, the presence of important natural resources such as natural gas, coal, copper and gold further increases the geopolitical importance of the region (Lale, 2019, s. 5910).

Another minority group living densely in Khuzestan and Bushehr provinces of Iran is Arabs and has a population of around 2 million. The fact that the province of Khuzestan has the most intense oil deposits of Iran on the one hand and is in a strategic position under the control of the Persian Gulf increases the importance of the region (Saraçl1, 2008, s. 170). In addition, Arabs live in other regions in Iran such as Fars, Bayer Ahmed, Tehran, Khorasan, Hürmüzgan and Çarmahal (Eroğlu, 2016, s. 31). Arabs, who maintain their tribal mentality and tribal ties today, have a nationalist perception of mind in terms of religious approach and language and 
mostly adopt the Shia creed (Saraçl1, 2008, s. 171). Another language spoken by minority groups in Iran is Arabic. The fact that the Qur'anic language and most of the sources related to Islamic Studies are in Arabic makes it possible to approach Arabic more moderately. For example, Arabs are given the right to press and publish in Arabic (Okyar, 2014, s. 241). Despite these privileges, Arabic mother tongue education is still out of question, especially in primary schools (Erendor, 2018, s. 317).

\section{Poverty and Natural Resources}

According to World Bank data, Iran's estimated gross domestic product (GDP) for the World 2019-2020 period is 463 billion USD and its population is 83 million (World Bank, 2020a). Iran is the second richest country in the world in terms of natural gas reserves and fourth richest in terms of oil reserves. In the country, whose general unemployment rate was around $12.1 \%$ in the period of April-June 2018, the youth (15-24 years old) unemployment rate was $28.3 \%$ in the same period, which is relatively high compared to the previous periods and the regional average (World Bank, 2020a; DEIKK, et al. ., 2020).

Poverty is evaluated as misery and poverty with a general definition. While poverty is considered absolute and relative within the framework drawn over income and consumption, poverty definitions evaluated within the framework of living conditions are urban and rural poverty, human poverty etc. (Evcim, et al., 2019, s. 292).

The regions where rural poverty is more common are the regions where oil production is seen or dominates the sea (Figure 5). The reason for this is that these geographies are less suitable for agriculture and the rural population has low salaries, shipping, oil, etc. It is run in sectors. Another reason for the high rate of rural population poverty is climatic conditions. Rural poverty is more prevalent in regions where Kurdish, Arab and Baloch ethnic groups live heavily (Figure 5). These regions are also the most backward regions of Iran.

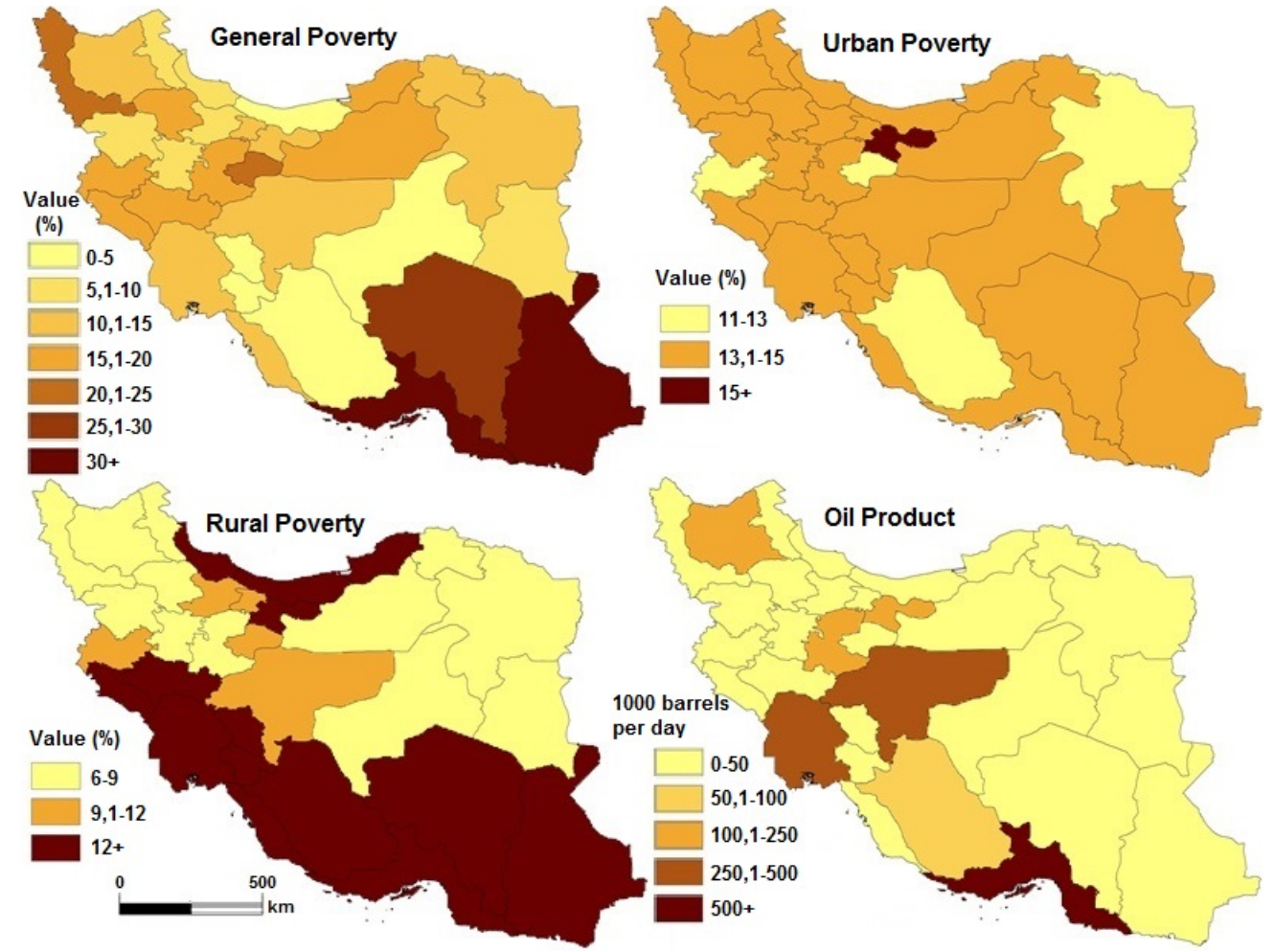

Figure 5. The Powerty and Oil Product of İran 
Due to migration from rural areas to big cities, the city in Iran where urban poverty is observed most is Tehran. While the poverty line in Tehran was 2 million 500 thousand Divisions in 2017, this amount increased to 4 million 500 thousand Divisions according to 2019 data (AA, 2020). Thus, with the decrease in income level in recent years, the poverty line has increased and the number of impoverished people has increased. While urban poverty is high in cosmopolitan Tehran, per capita income is generally higher in Shiite, Persian and central provinces (Doğan and Alizadeh, 2020, p. 180). However, economically, almost all cities of Iran are on the brink of poverty at the regional level (Figure 5).

The region with the highest level of general poverty is the Baluchistan province of Sistan-Baluchistan. Both being Sunni and having close relations with neighboring states to which they are ethnically related and also controlling an important strategic point give the impression that the region is deliberately left poor by Iran (Figure 5). On the other hand, in periods when oil and natural gas revenues increase, per capita income in Persian and Shia regions also increases. The reason why the general poverty is relatively low in regions where Sunni, Turkmen and Kurdish elements live, except for the region where Balochi ethnic structure lives, is related to the more developed industrial, agricultural and transportation activities in these regions.

\section{Results}

A possible internal conflict risk map of Iran was created by evaluating the 15 parameters discussed in the previous section together. These 15 parameters were evaluated using Analytical Hierarchy Method, one of the Multi Criteria Decision Making techniques, and the risk map in Figure 6 was produced. The risk is at the lowest level in the regions that are Persian in terms of ethnicity and Shia in terms of sectarian. The regions with the highest risk are SistanBaluchistan, West Azerbaijan and Kurdistan. These provinces are followed by Gulistan, Gilan and Kermanshah. In terms of internal fragility, it is seen that these areas with high risk are Sunni in terms of sectarianism. However, this Sunni population constitutes only $10 \%$ of the population of Iran. Therefore, it is not possible to say that they could be very effective in Iranian internal fragility. After these states, the two provinces with high risk are Tehran and Kuzistan. Tehran, where different ethnic and sectarian groups with a dense urban population live together and where economic stratification is clearly seen, appears as the most important province of a possible Iranian civil war. For this reason, it poses much more danger than the other states above with the risk of internal conflict. 


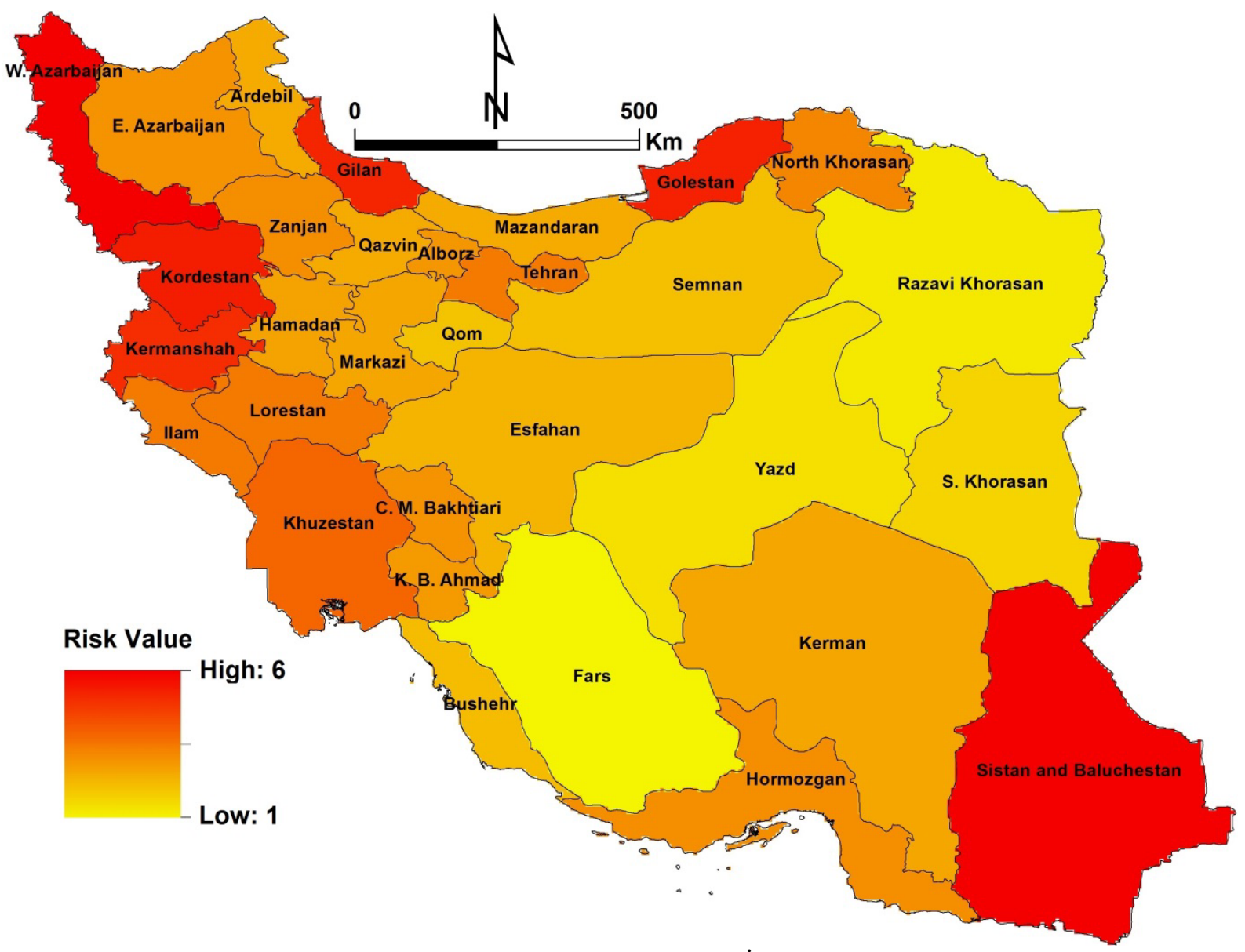

Figure 6. The Risk map of İran.

East Azerbaijan, Luristan, Ilam, Zanjan, Kuzey Horosan, Hürmüzgan and Alborz appear as provinces with moderate risk. While Qom Semnan South Horosan Bushehr carries much less risk, in Fars, Yazd and Razavi Horosan the risk of internal conflict is almost negligible. When we look at the internal conflict risk situation of the provinces in Iran in general, we can say that the central states do not pose a risk to a large extent, and the risk is very high in the northnorthwest and southeast provinces. We also see that these areas are the most important geopolitical and geostrategic areas of Iran.

In addition, in a possible Iranian civil war, it is seen that there will be polarization in at least 5 different regions. The most important Sunni Kurds and Lure of the polarization field denominational bensup in a similar manner with the intense border with Turkey where they live the majority of the Sunni population in the province of Sistan-Baluchestan be seen. It is possible to add to these areas the regions where Azerbaijani Turks live in the north and northwest and the provinces where the Sunni Turkmen live in the north. It is possible to talk about a homogeneous area of Persian and Shia origin and state-sponsored in the center of the Iranian Plateau, which is reversed of these separatist areas.

Iran, in a possible civil war in Turkey, will also change the fate of all the neighboring countries and the Middle East. Indeed, although it poses a threat in many ways, it is also a balancing factor in many aspects. In addition, a possible civil war in Iran which has a large Shiite population and ethnic diversity will cause a large wave of migration to Turkey, commercial shrinkage and new border operations. A possible prolonged Civil war in Iran may also cause instability in Turkey and other neighboring countries and it can even cause serious problems. 


\section{Acknowledgement}

We do want to thank the Scientific Research Projects Governing Unit of Gaziantep University for their financial contribution to this study.

\section{References}

Adıbelli, B., (2017). Pax Persica: İran jeopolitiği. IQ Kültür Sanat Yayıncılık, İstanbul.

Altundeğer, N. and Yılmaz, M., (2016). İç savaştan bölgesel istikrarsızlı̆̆a: Suriye krizinin Türkiye'ye faturası. Süleyman Demirel Üniversitesi İktisadi ve İdari Bilimler Fakültesi Dergisi 21 (1): 289-301.

Amiri , R. E., (2010). Foreign Policy of Iran after Islamic revolution. Journal of Politics and Law 3 (2): 199-206.

Ansari, A. and Aarabi, K., (2019). Ideology and Iran's Revolution: How 1979 Changed the World. Tony Blair Institute for Global Change, United Kingdom.

Atmaca, M., (2012). İran'da Sünni grupların sosyal, kültürel, dini yapılanmaları ve Türkiyenin bu gruplara yönelik politikaları. T.C. Başbakanlık Yurtdışı Türkler ve Akraba Topluluklar Başkanlığı, Ankara.

Attar, A., (2006). Iran'ın etnik yapısı. Divan Yayıncılık, Ankara.

Bahurmoz, A., (2006). The analytic hierarchy process: A methodology for win-win management. JKAU: Econ. \& Adm. 20 (1): 3-16.

Barnes , J. and Jaffe, A. M., (2006). The Persian Gulf and the geopolitics of oil. Survival 48 (1): 143-162.

Barrett, R. C., (2014). Islam: ideology and conflict, The JSOU Press, Florida.

Beşiriye, H., (2009). Iran'da devlet, toplum ve siyaset. Ağaç Kitapevi, İstanbul.

Bilgetürk, İ., (2018). İran'ın Suriye politikası bağlamında Şiilik ve Şii milisler. Ankasam Bölgesel Araştırmalar Dergisi 2 (2): 398-438.

Birsel, H., (2013). İran'ın jeopolitik özelliklerinin değişik açılaran incelenmesi. In Arap baharında son durak İran, H. Birsel (Ed.) 19-38, IQ Kültür Sanat Yayıncılık, İstanbul.

Boroumandi, M., Khamehchiyan, M. and Nikoudel, R., (2014). Using of analytic hierarchy process for landslide hazard zonation in Zanjan province, Iran. Engineering Geology for Society and Territory 2 (XIII): 951-955.

Boylu, E. and Temizyürek, F., (2015). İran'da türkçenin dünü ve bugünü. Hacettepe Üniversitesi Yabancı Dil Olarak Türkçenin Araştırılması Dergisi 2 (2): 95-106.

Canyurt, D., (2018). Kazananı olmayan savaş "Suriye iç savaşı": Neden bitmedi, barış nasıl gelebilir? Uluslararası Yönetim Iktisat ve Issletme 14 (4): 1103-1120.

Chitadze, N., (2012). Geopolitical interests of Iran in south caucasus and Georgian-Iranian relations. Journal of Social Sciences 1 (2): 5-12.

Collier, P., (2000). Economic Causes of civil conflict and their 1mplications for policy. Planeación y Desarrollo XXXI (1): 5-26.

Collier, P. and Hoeffle, A., (2004). Greed and grievances in civil war. Oxford Economic Papers 56: 563-595.

Çetin, B., (2017). Toplumsal bir eylem biçimi olarak traktör futbol takımı bağlamında jeopolitik tasavvur oluşturma süreci. The Journal of Academic Social Science Studies 62: 317331.

DEİ, TİM and KPMG. (2020). Ambargo sonrast Iran ekonomik ve ticari etki analizi.//www.deik.org.tr:https://www.deik.org.tr/uploads/ambargo_sonrasi_iran_ekon omik_ve_ticari_etki_analizi.pdf adresinden alınmıştır. LastAccess: $18.09 .20 \overline{2} 0$.

Dias, A. M., (2013). Introduction: Understanding conflict and processes of state formation, reconfiguration and disintegration in the Horn of Africa. In State and Societal Challenges in the Horn of Africa: Conflict and Processes of State Formation, 
Reconfiguration and Disintegration, A. M. Dias (Ed.) 3-13, Center of African Studies (CEA)/ISCTE-IUL, Lisbon.

Davutoğlu, A., (2011). Küresel bunalım. Küre Yayınları, İstanbul.

Davutoğlu, A., (2012). Stratejik derinlik. Küre Yayınları, İstanbul.

Deniz, A., (2015). Kimlik, küreselleşme, sivil toplum, sosyal medya. In Toplumsal Hareket Teorileri ve Ortadoğu İsyanları, A. Deniz (Ed.) 65-100, Orion Kitapevi, Ankara.

Doğan, K. and Alizadeh, N., (2020). İran'da rant üretici politikaların gelir dağılımı üzerindeki etkilerinin etnik, mezhepsel ve bölgesel özelliklere göre incelenmesi. Ankara SBF Dergisi 75 (1): 163-191.

World Bank (2020). www.worldbank.org/en/country/iran/overview. https://www.worldbank.org/en: https://www.worldbank.org/en/country/iran/overview adresinden alınmıştır. LastAccess:11.09.2020.

World Bank (2020). www.worldbank.org/en/country/iran/publication/economic. www.worldbank.org/en/:

https://www.worldbank.org/en/country/iran/publication/economic-update-october2019 adresinden alınmıştır.

Egnal, M., (2011). The economic origins of the civil war. OAH Magazine of History 25 (2): 2933.

Ehteshami , A. and Mohammadi, A., (2017, June). Iran's discourses and practices in the Mediterranean since 2001. Roma, Italy.

Einian, M., and Souri, D., (2020). Poverty maps of Iran. econ.cam.ac.uk: http://www.econ.cam.ac.uk/people-

files/faculty/km418/IIEA/IIEA_2018_Conference/Papers/Einian_Poverty\%20Maps\% 20of\%20Iran.pdf adresinden alınd1. Last Access: 08. 09. 2020.

Ekşi, M., (2017). İran'ın transosyal ve teopolitik - Şiilik - temelli kamu diplomasisi. Bölgesel Araştırmalar Dergisi 1 (2): 46-66.

Elçi, İ.H., (2019). İran jeopolitiğinin enerji politiklarına etkisi. International Journal of Political Studies 5 (3): 154-173

Erendor, M., (2018). Iran'da türk kimliği. Kamer Yayınları, İstanbul.

Eroğlu, Y., (2016). Demografik özelliklerin İran jeopolitiğine etkisi. İzmir Katip Çelebi Üniversitesi Sosyal Bilimler Enstitüsü Uluslararası İlişkiler AnaBilim Dalı Yüksek Lisans Tezi, İzmir.

Erol, M.S. and Bilgetürk, İ., (2020). Mehdilik anlayışı kapsamında İran dış politikası üzerine bir inceleme. Ankasam Bölgesel Araştırmalar Dergisi 4 (1): 240-280.

Evcim, N., Güneş, S. and Karaalp Orhan, H.S., (2019). Yoksulluk ve ekonomik göstergeler arasındaki ilişki: Mena bölgesi analizi. Pamukkale Üniversitesi Sosyal Bilimler Enstitüsü Dergisi, (36): 291-310.

Fanni, Z., (2006). Cities and urbanization in Iran after the Islamic revolution. Cities 23(6): 407411.

Fearon, J. D. and Laitin, D. D., (2003). Ethnicity, insurgency, and civil war. American Political Science Review, 97 (1): 75-90.

Florida, R. and Mellander, C., (2017). The Geography of economic segregation. CESIS Electronic Working Paper Series 457: 1-21.

Gelvin, J., (2014). Arap İsyanlarını Anlamak. In Ortadoğu: Direniş, Devrim, Emperyalizm, Y. Çetinkaya (Ed.) 63-88, İletişim Yayıncılık, İstanbul

Gersovitz, M. and Kriger, N., (2013). What Is a Civil War?A Critical Review of Its Definition and (Econometric) Consequences. The World Bank Research Observer 28 (2), 159-190.

Golmohammadi, V., (2019). The Foreign Policy of the Islamic Republic of Iran: Prospects for Change and Continuity. All Azimuth 8 (1): 93-102. 
Gürkaş, B., (2007). Bölgesel Bir Güç Olarak İran'ın Jeopolitik Konumu. Marmara Üniversitesi Ortadoğu Enstitüsü Ortadoğu Siyasi Tarihi ve Uluslararası İlişkiler Ana Bilim Dalı Yüksek Lisans Tezi, İstanbul.

Hafeziniya, M., (2017). Iran Jeopolitiği ve Siyasi Coğrafyası. İraniyat Yayınları, Ankara.

http://www.mfa.gov.tr. (2019). www.mfa.gov.tr: http://www.mfa.gov.tr/iran-kunyesi.tr.mfa adresinden alınmıştır. Last Access: 09. 04. 2020.

https://www.aa.com.tr. (2019). www.aa.com.tr: https://www.aa.com.tr/tr/ulkeprofilleri/iran/903459 adresinden alınmıştır. Last Access: 09. 04. 2020.

İşbilen, E., (2009). Nükleer Satranç, Ozan Yayıncılık, İstanbul.

Jackson, R., (2001). The state and internal conflict. Australian Journal of International Affairs 55 (1): 65-81.

Jones, S., (2009). The Islamic Republic of Iran: An introduction. House of Commons Library, United Kingdom.

Karadağ, S., (2019). Değişen Dengeler ve İran Kürtleri. İnsamer, İstanbul.

Karadeniz, Y., (2012). İran Tarihi (1700-1925). Selenge Yayınları, İstanbul.

Kim, H. S., (1998). Analysis of the Gap Between Growth and Quality of Life in the Third World. National Social Science Journal 10 (2): 84-90.

Kim, H. S., (2006). The Determinants of Internal Conflict in the Third World. The Whitehead Journal of Diplomacy and International Relations 91: 91-106.

Konukçu, Y., (2018a). Jeopolitik Güç Mücadelesi ve Basra Körfezinin Önemi. Elektronik Siyaset Bilimi Araştırmaları Dergisi 9 (2): 19-36.

Konukçu, Y., (2018b). İran'ın Bölgesel Güvenlik Stratejisi: Bir Güç Döngüsünün Değerlendirilmesi. Bitlis Eren Üniversitesi Akademik İzdüşüm Dergisi 3 (3): 74-91.

Kum, G., Sönmez, M. E. and Karabaş, M., (2019). Determination of Solar Energy Potential in Gaziantep Province by Analytical Hierarchy Process Method (AHP). Journal of Geography 39: 61-72.

Lale, A., (2019). İran'ın Beluç Sorunu. International Social Science Studies Journal, 5 (47): 5908-5917.

Massey, D. S. and Danton, N. A., (1993). American Apartheid: Segregation And The Making of the Underclass. Harvard University Press, Cambridge, Ma.

Macdonald, H., (2002). Geopolitics and Middle East Conflict. Norwegian Institute for Defence Studies, Oslo.

Okyar, O., (2014). İran ve Demokrasi. Ötüken Neşriyat, İstanbul.

Omelicheva, M. Y., (2012). Russia's Foreign Policy Toward Iran: A Critical Geopolitics Perspective. Journal of Balkan and Near Eastern Studies, 14 (3): 331-344.

Özdemir, M. S. and Saaty, T. L., (2006). The Unknown in Decision Making What to Do About It. European Journal of Operational Reserarch 174: 349-359.

Parsons, T. and Merton, R. K., (2011). Conflict and Critical Theories. In The Social Lens : An Invitation to Social and Sociological Theory, L. Coser, R. Dahrendorf, R. Collins and K. Allan (Ed.) 211-241, Pine Forge Press/Sage Publications, Los Angeles.

Pullan, W., (2011). Conflict In Citles And The Contested State. University of Cambridge, Cambridge.

Rakel, E. P., (2008). The Iranian political elite, state and society relations, and foreign relations since the Islamic revolution, University of Amsterdam, Amsterdam.

Ranjipour, A., (2020). Poverty in Iran: An introduction. iranwire.com9: https://iranwire.com/en/features/5829 adresinden alınd1. Last Access: 05. 12. 2020.

Saaty, T. L., (1990). How to make a decision: the analytic hierarchy process. European Journal of Operation Research 48: 9-26.

Salihi, E., (2019). Orta Doğu'da oluşan yeni dengeler ve Şii Hilali söylemi. Bilgi Strateji Dergisi, 2 (4): 183-202). 
Sanyürek, M.B., (2018). Şii jeopolitiği ve İran. Socıal Mentaltty And Researcher Thınkers Journal 4(14):1139-1160.

Saraçlı, M., (2008). İran'da azınlıklar. Akdaemik Orta Doğu 2 (4): 159-180.

Sarıkaya, Y., (2008). Tarihi ve jeopolitik boyutlarıla Iran'da miliyetçilik. Ötüken Neşriyat, İstanbul.

Sönmez, M. E., (2011). An Analysis of the earthquake damage risk based on geographic information system (GIS) As example: Zeytinburnu (Istanbul). Türk Coğrafya Dergisi 56: 11-22.

Stratfor

Stratfor

Worldview.

https://worldview.stratfor.com/:http://www.pilsch.gatech.edu/Readings/GeopoliticsOfI ran.pdf adresinden alınd1. Last Access: 01 15. 01. 2021.

Şen, A. and Şen, Y., (2015). Sosyal medya, iletişim hakk1 ve ifade özgürlüğü üzerine bir değerlendirme. Gazi Üniversitesi İktisadi ve İdari Bilimler Fakültesi Dergisi 17 (2): 122-136.

Şen, G. and Güngör, E., (2018). The use of analytic hierarchy process method in choosing the best tree type for industrial plantations: The case of Kastamonu Province. Turkish Journal of Forestry 19 (1): 63-75.

Tüysüzoğlu, G., (2011). Toplumsal kimliğe dayalı güvenlikleştrimenin siyasal sorunlar bağlamında irdelenmesi:Belucistan örneği. Güvenlik Stratejileri 11 (21): 39-87.

Tüysüzoğlu, G., (2013). Kürt ve Beluci ulusçuklarının benzeşen ayrışan yönleri. In Ortadoğu y1llığ 2013, K. İnat (Ed.) 415-442, Aç1lım Kitap, İstanbul.

Ünal, Ö. F., (2012). Performans değerlemede analitik hiyerarşi prosesi (AHP) uygulamaları. Sosyal Bilimler Araştırmaları Dergisi I: 37-55.

Wind, Y., \& Saaty, T. L., (1980). Marketing application of the analytic hierarchy process. Management Science 26 (7): 641-658.

Yavuz, H., (2014). İran'ın etnik kompozisyonu ve siyasal güç açısından etkileri. In İran: Değişen İç Dinamikler ve Türkiye-İran İlişkileri, T. Soyalp (Ed.) 81-100, Gazi Kitapevi, Ankara.

Yenisey, G., (2008). Iran'da etnopolitik hareketler 1922-2004. Ötüken Neşriyat, İstanbul.

Zeinolabedin, Y., Yahyapour, M. S. and Shirzad, Z. (2009). Geopolitics and environmental issues in the Caspian Sea. Caspian J. Env. Sci. 7 (2): 113-121. 